\title{
Comparative study of Deferiprone versus Deferiprone with Deferasirox as iron chelation therapy in Thalassemic children
}

\author{
SYEDA JARKA JAHIR ${ }^{1}$, SAYEEDA ANWAR² ${ }^{2}$ AKM AMIRUL MORSHED ${ }^{3}$, AFIQUL ISLAM $^{4}$, \\ KABIRUL ISLAM ${ }^{5}$
}

\begin{abstract}
Background: Combination therapy of Deferiprone (DFP) with Deferasirox (DFX) is an efficacious and safe modality to reduce serum ferritin in multi-transfused children with thalassemia.

Objectives: To compare the efficacy of Deferiprone versus Deferiprone with Deferasirox as iron chelation therapy of transfusion dependent thalassemia children.

Materials and Methods: A non-randomized control clinical trial was done in department of Pediatric Hematology and Oncology, Dhaka Medical College Hospital and Bangladesh Thalassemia Hospital in Dhaka during the period of October 2016 to September 2017. Thirty children with transfusion dependent thalassemia major between 3 to 12 years of age were included in each group in this study. Children with thalassemia minor, after splenectomy, with comorbidities and on other iron chelation therapy were excluded from this study.
\end{abstract}

Results: Among total enrolled 60 cases in this study, initial mean serum ferritin level was $3397.48 \pm 774.48 \mathrm{ng} / \mathrm{ml}$ in DFP-monotherapy group and $3413.70 \pm 1114.05 \mathrm{ng} /$ $\mathrm{ml}$ in DFP-DFX combination group. Mean serum ferritin level at $6^{\text {th }}$ month was found $2730.63 \pm 839.91 \mathrm{ng} / \mathrm{ml}$ in DFP-monotherapy group and $1654.20 \pm 934.90 \mathrm{ng} / \mathrm{ml}$ in $D F P-D F X$-combination group which shows rapid reduction of serum ferritin level in DFP-DFX-combination group. 12 (40.0\%) patients had arthralgia in DFPmonotherapy group and 5(16.7\%) patients had vomiting in DFP-DFX-combination group. No abnormalities seen in liver and renal function tests.

Conclusion: Combination therapy with Deferiprone and Deferasirox is more effective in reduction of iron overload and drug related complications in transfusion dependent thalassemia patients.

Keywords: Thalassemia major, iron overload, outcome of iron chelation therapy, Deferiprone monotherapy and Deferiprone with Deferasirox combination therapy.

\section{Introduction}

Iron overload is inevitable when thalassemia major (TM) patients receive regular blood transfusion. 100 $200 \mathrm{ml}$ of pure red blood cell/kg body weight/year transfusion accumulates $0.32-0.64 \mathrm{mg}$ of iron $/ \mathrm{kg} /$ day.

1. Assistant Professor (Pediatrics), Department of Pediatrics, Dhaka Medical College, Dhaka, Bangladesh.

2. Professor and Head, Department of Pediatrics, Dhaka Medical College, Dhaka.

3. Professor and Head, Department of Pediatric Hematology and Oncology, Dhaka Medical College, Dhaka.

4. Professor, Department of Pediatric Hematology and Oncology, BSMMU, Dhaka.

5. Senior Medical Officer, Bangladesh Thalassemia Hospital, Dhaka

Correspondence: Dr. Syeda Jarka Jahir, Department of Pediatrics, Dhaka Medical College Hospital, Dhaka, Bangladesh. Cell:01718867769, Email:jarka05@yahoo.com

Received: $21 / 07 / 2018$

Accepted: 23/04/2019
In individuals who are poorly transfused absorption rises to $3-5 \mathrm{mg} /$ day or more. In patients with thalassemia who do not receive any transfusion, iron absorption increases several fold. ${ }^{1}$ Free iron generates harmful free radicals that damage lipid membranes organelles and DNA causing cell death, fibrosis, increased risk of infections, neoplasia, liver disease with fibrosis, cirrhosis and hepatocellular carcinoma. ${ }^{1,2}$ Iron accumulation is toxic to many tissues causing endocrine complications: pituitary damage leading to hypogonadism, growth retardation, delayed puberty, diabetes, hypothyroidism and hypoparathyroidism. ${ }^{3}$

Chelation therapy aims to balance the rate of iron accumulation from blood transfusion by increasing iron excretion in urine and or faces. Because iron is 
also required for essential physiological purposes, a key challenge of chelation therapy is to balance the benefits of chelation therapy with the unwanted effects of excessive chelation. Careful dose adjustment and treatment regimens are necessary to avoid excess chelation as iron levels fall. ${ }^{1}$ The second major challenge in chelation therapy is to achieve regular adherence to treatment regimens throughout a lifetime. Poor adherence can result from prolonged subcutaneous night infusions for 8-12 hour 5-7 nights a week of iron chelating agentsDesferioxamine (DFO), local infection, intolerance of a particular chelator, psychosocial issues, psychological wellbeing, lack of institutional support and family, unavailability, side effects of variable severity, patient's refusal or non-compliance. ${ }^{1,4}$ Oral iron chelator-Deferiprone (DFP) monotherapy significantly improves myocardial siderosis in TM. ${ }^{5,6}$ Side effects include agranulocytosis (in about $1 \%$ of patients), GI symptoms, arthralgia, zinc deficiency and fluctuating transaminases levels. ${ }^{1}$ DFP can be used in combination with another oral iron chelatorDeferasirox (DFX). ${ }^{1,7}$ DFX reduces parenchymal labile iron of tissues. ${ }^{1}$ Combination therapy of DFPDFX has been used successfully to overcome intolerance to both drugs. Combining the two drugs is also a promising alternative for the treatment of severe cardiac iron overload. ${ }^{8}$

\section{Materials and Methods:}

From October 2016 to September 2017, sixty children aged between 3 to 12 year presenting with transfusion dependent $\beta$-thalassemia major or $\mathrm{E}-\beta$-thalassemia having serum ferritin level $>1000 \mathrm{ng} / \mathrm{ml}$ seeking treatment in department of Pediatric Hematology and Oncology, Dhaka Medical College Hospital (DMCH) and Bangladesh Thalassemia Hospital in Dhaka were included in this clinical trial. Children with thalassemia minor, patients after splenectomy, with comorbidities (chronic illness, malignancy), on other iron chelation therapy were excluded. Among 60 patients 30 were assigned to group A and 30 to group $B$ by lottery method. The following parameters were measured and recorded on initial visit as base line: body weight, size of liver and spleen, serum ferritin level, CBC with RBC indices, SGPT, creatinine and other necessary individualized investigations. Ethical permission was taken from Ethical Review Board of DMC and informed written consent was taken from the parents as well as patients where applicable.
Participants in Group A received DFP monotherapy (63.8 $-78.2 \mathrm{mg} / \mathrm{kg} /$ day in 3 divided doses daily) and group $B$ received combination therapy of DFP-DFX (60-75 mg/kg/day in 3 divided doses $+23-31.25$ $\mathrm{mg} / \mathrm{kg} /$ day in single dose daily respectively) for 6 months. The dosages were adjusted by the physicians according to body weight in $\mathrm{kg}$. By clinical and laboratory investigations the patients were followed up monthly for 6 months. Both parents and patients were interviewed for particulars and history. Findings of history, physical examinations and laboratory investigations were recorded in a questionnaire. Statistical analysis was done by SPSS-22.0 for Windows. Mean values were calculated for continuous variables, quantitative observations by frequencies and percentages. Unpaired and paired t-test was used to analyze continuous variables. $P$ value $<0.05$ was considered as statistically significant.

\section{Results:}

It was observed that out of 60 patients majority belonged to age $<9$ years in both groups, 22(73.4\%) in DFP-monotherapy group and $23(76.7 \%)$ in DFPDFX-combination group. The mean age was found $7.42 \pm 2.50$ years in DFP-monotherapy group and $7.48 \pm 2.38$ years in DFP-DFX-combination group. Age difference was not statistically significant $(p>0.05)$ between the groups. Male was found $22(73.3 \%)$ in DFP-monotherapy group and $13(43.3 \%)$ in DFP-DFX combination group; female was $8(26.7 \%)$ in monotherapy group and $17(56.7 \%)$ in combination group. Mean weight was found $19.08( \pm 4.13) \mathrm{kg}$ in DFP-monotherapy group and $21.03( \pm 7.69) \mathrm{kg}$ in DFP-DFX combination group. No statistically significant $(p>0.05)$ difference was observed between the groups. Initial mean serum ferritin level was $3397.48 \pm 774.48 \mathrm{ng} / \mathrm{ml}$ in DFPmonotherapy group and $3413.70 \pm 1114.05 \mathrm{ng} / \mathrm{ml}$ in DFP-DFX combination group (Table-I) that was not statistically significant $(p>0.05)$. At $3^{\text {rd }}$ month mean serum ferritin level was $3151.62 \pm 770.39 \mathrm{ng} / \mathrm{ml}$ in DFP-monotherapy group and $3158.63 \pm 1077.33 \mathrm{ng} /$ $\mathrm{ml}$ in DFP-DFX combination group that was not statistically significant $(p>0.05)$. Mean serum ferritin level at $6^{\text {th }}$ month was found $2730.63 \pm 839.91 \mathrm{ng} / \mathrm{ml}$ in DFP-monotherapy group and $1654.20 \pm 934.90$ $\mathrm{ng} / \mathrm{ml}$ in DFP-DFX-combination group that shows significantly rapid reduction of serum ferritin level in the combination group ( $p$ value 0.001 ). 
BANGLADESH J CHILD HEALTH 2019; VOL 43 (3) : 154 Comparative study of Deferiprone versus Deferiprone with Deferasirox

Table-I

Comparison of mean serum ferritin levels between two groups $(n=60)$

\begin{tabular}{|c|c|c|c|c|c|}
\hline \multirow[t]{2}{*}{ Serum ferritin (ng/ml) } & \multicolumn{2}{|c|}{ DFP-monotherapy $(n=30)$} & \multicolumn{2}{|c|}{ DFP-DFX-combination(n=30) } & \multirow[t]{2}{*}{$p$ value } \\
\hline & Mean & $\pm S D$ & Mean & $\pm S D$ & \\
\hline Serum ferritin initial & 3397.48 & \pm 774.48 & 3413.70 & \pm 1114.05 & $0.948^{\text {ns }}$ \\
\hline Serum ferritin at $3^{\text {rd }}$ month & 3151.62 & \pm 770.39 & 3158.63 & \pm 1077.33 & $0.977^{\mathrm{ns}}$ \\
\hline Serum ferritin at $6^{\text {th }}$ month & 2730.63 & \pm 839.91 & 1654.20 & \pm 934.90 & $0.001^{\mathrm{s}}$ \\
\hline
\end{tabular}

$\mathrm{s}=$ significant; ns=not significant; $\mathrm{P}$ value reached from unpaired t-test

Table II

Difference in mean serum ferritin level within DFP-monotherapy group between initial vs at $3^{\text {rd }}$ month, at $3^{\text {rd }}$ month vs at $6^{\text {th }}$ month and initial vs at $6^{\text {th }}$ month

\begin{tabular}{lccc}
\hline Serum ferritin $(\mathrm{ng} / \mathrm{ml})$ & Mean $\pm(\mathrm{SD})$ & Mean $\pm(\mathrm{SD})$ & $\mathrm{p}$ value \\
\hline Initial vs at $3^{\text {rd }}$ month & $3397.48( \pm 774.48)$ & $3151.62( \pm 770.39)$ & $0.001^{\mathrm{s}}$ \\
At $3^{\text {rd }}$ month vs at $6^{\text {th }}$ month & $3151.62( \pm 770.39)$ & $2730.63( \pm 839.91)$ & $0.001^{\mathrm{s}}$ \\
Initial vs at $6^{\text {th }}$ month & $3397.48( \pm 774.48)$ & $2730.63( \pm 839.91)$ & $0.001^{\mathrm{s}}$ \\
\hline
\end{tabular}

$p$ value reached from paired t-test

Table II shows in DFP-monotherapy group, mean serum ferritin level was statistically significant $(p<0.05)$ when compared to initial vs at $3^{\text {rd }}$ month, at $3^{\text {rd }}$ month vs at $6^{\text {th }}$ month and initial vs at $6^{\text {th }}$ month.

Table III

Difference in mean serum ferritin levels within DFP-DFX-combination group between initial vs at $3^{\text {rd }}$ month, at $3^{\text {rd }}$ month vs at $6^{\text {th }}$ month and initial vs at $6^{\text {th }}$ month

\begin{tabular}{lccc}
\hline Serum ferritin & Mean $\pm(S D)$ & Mean $\pm(S D)$ & p value \\
\hline Initial vs at $3^{\text {rd }}$ month & $3413.70( \pm 1114.05)$ & $3158.63( \pm 1077.33)$ & $0.001^{\text {s }}$ \\
At $3^{\text {rd }}$ month vs at $6^{\text {th }}$ month & $3158.63( \pm 1077.33)$ & $1654.20( \pm 934.90)$ & $0.001^{\text {s }}$ \\
Initial vs at $6^{\text {th }}$ month & $3413.70( \pm 1114.05)$ & $1654.20( \pm 934.90)$ & $0.001^{\text {s }}$ \\
\hline
\end{tabular}

$p$ value reached from paired t-test

Table III shows in DFP-DFX-combination group, mean serum ferritin level was statistically significant $(p<0.05)$ when compared to initial vs at $3^{\text {rd }}$ month, at $3^{\text {rd }}$ month vs at $6^{\text {th }}$ month and initial vs at $6^{\text {th }}$ month.

Twelve (40\%) patients had arthralgia in DFPmonotherapy group and not found in DFP-DFXcombination group as dose of DFP was significantly low in group B. Five (16.7\%) patients had vomiting in DFP-DFX-combination group and not found in DFPmonotherapy group which were statistically significant $(p<0.05)$ between two groups. In this study, there were no significant differences in pre and post values of renal and liver function tests in both groups before and after iron chelation therapy.

\section{Discussion:}

The mean age was found $7.42 \pm 2.50$ years in DFPmonotherapy group and $7.48 \pm 2.38$ years in DFPDFX-combination group showing majority of cases was $<9$ years in this study but Gomber et al. ${ }^{7}$ found mean age $11.6( \pm 6.21)$ years and Riaz et al. ${ }^{9} 10.8$ $( \pm 4.5)$ years in their study. Study of Mourad et al. observed no significant differences in the initial serum ferritin levels, age, sex distribution between the two groups and all observations were approximately similar to our study. ${ }^{10}$ In a study of Hassan and Tolba the mean weight was not statistically significant between 2 groups as in our study. ${ }^{11}$ In the present study mean serum ferritin level initially was not statistically significant $(p>0.05)$ when compared 
between two groups. At $3^{\text {rd }}$ month mean serum ferritin level was not statistically significant $(p>0.05)$ when compared between two groups due to increment of serum ferritin level in 10 patients (33.3\% cases) of DFP-DFX combination group. At $6^{\text {th }}$ month mean serum ferritin level significantly reduced in DFP-DFXcombination group. Gomber et al. observed similar findings after 12 months of respective chelation therapy and the DFP-DFX combination therapy was found more efficacious in causing fall in serum ferritin levels compared to DFP and DFX monotherapy ( $P=0.035$ and 0.040 , respectively). The combination of DFP and DFX was found to be the most efficacious in our study due to significant fall in mean serum ferritin values. These results are in agreement with study of Farmakiet et al. ${ }^{12}$ and other case reports of Baloccoet et al. and Voskaridouet et al. ${ }^{13,14}$ In this study it was observed that in DFP-monotherapy group, mean serum ferritin level was significantly decreased when compared to initial vs at $3^{\text {rd }}$ month, at $3^{\text {rd }}$ month vs at $6^{\text {th }}$ month and initial vs at $6^{\text {th }}$ month. Waheed et al. also found significant difference between basal serum ferritin and final serum ferritin in DFP-monotherapy group $(p=0.001) .{ }^{15}$ In this current study it was observed that in DFP-DFXcombination group, mean serum ferritin level was significantly decreased $(p<0.05)$ when compared to initial vs at $3^{\text {rd }}$ month, at $3^{\text {rd }}$ month vs at $6^{\text {th }}$ month and initial vs at $6^{\text {th }}$ month. In a study of Waheed et al. significant difference was also found between basal serum ferritin and final serum ferritin. ${ }^{15}$ In the present study mean dose of drugs was found 72.59 $( \pm 3.76) \mathrm{mg} / \mathrm{kg}$ body weight/ day of DFP in monotherapy group (Group A) and $68.68( \pm 4.84)$ $\mathrm{mg} / \mathrm{kg}$ body weight/ day of DFP and $27.98( \pm 2.13)$ $\mathrm{mg} / \mathrm{kg}$ body weight/ day of DFX in combination group (Group B) which shows dose of DFP was significantly higher in group A (DFP-monotherapy). Totadri et al. used DFP and DFX at a mean doses of were $84.4 \pm$ $5.2(61-100 \mathrm{mg} / \mathrm{kg} / \mathrm{day})$ and $33.4 \pm 5.2(20-40 \mathrm{mg} /$ $\mathrm{kg} /$ day), respectively. ${ }^{16}$ But mean dose of DFX was $23.5 \pm 4.9 \mathrm{mg} / \mathrm{kg} /$ day and the maximum dose was $40 \mathrm{mg} / \mathrm{kg} /$ day in a study done by Eshghi et al. ${ }^{17}$

In this study it was observed that $12(40.0 \%)$ patients had arthralgia in DFP-monotherapy group and not found in DFP-DFX-combination group. Five (16.7\%) patients had vomiting in DFP-DFX-combination group and not found in DFP-monotherapy group. Which were statistically significant $(p<0.05)$ between two groups. In a study done by Ellis J, had shown that erosive arthritis was $5 \%$ to $20 \%$ in DFP-monotherapy group in which the dose was $75-100 \mathrm{mg} / \mathrm{kg} / \mathrm{day} .{ }^{18}$ In this present study it was observed that mean SGPT and serum creatinine level at initial and $6^{\text {th }}$ month were not statistically significant $(p>0.05)$ when compared between two groups. No abnormalities seen in liver and renal function tests. Gomber et al and Hagag et al also found similar findings. 7,19

\section{Conclusion}

Deferiprone alone significantly excretes iron from the body in transfusion dependent Thalassaemia major patients. But combination therapy with Deferiprone and Deferasirox is more significantly effective in reduction of iron overload and drug related complications.

\section{References:}

1. Sara T and Alan C. Blood transfusion. In: Cappellini MD, Cohen A, Porter J, Taher A, Viprakasit V, editors. Guidelines for the management of transfusion dependent Thalassaemia (TDT). 3rd edition. TIF publication no.20: 2014: 28-125.

2. Anderson LJ, Holden S, Davies B, Prescott E, Charrier CC, Bunce NH et al. Cardiovascular T2* (T2 star) magnetic resonance for the early diagnosis of myocardial iron overload. Eur Heart J. 2001;22:2171-79.

3. Kumar A, Abbas AK, Aster JC. Red blood cell and bleeding disorders. In: Kumar A, Abbas AK, Aster JC, editors. Robbins and Cortan Pathologic basis of disease. 9th edition. Philadelphia: ELSEVIER: 2015; 14: 638-41.

4. Janet L, Kwiatkowski MD. Hemoglobinopathies. In: Lanzkowsky P, editor. Manual of Pediatric Hematology and Oncology. 5th Edition. ELSEVIER: 2011; 8: 231-40.

5. Alan RC, Renzo G, Dudley JP, Melody JC, Elliott V. Thalassemia syndromes. In: Andrew JK, Douglas RH, editors. ASH Education Book. ELSEVIER: 2004; 1: 14-34.

6. Michael R, DeBaun, Melissa J, Frei-Jones, Elliott P, Vichinsky. Hemoglobinopathies. In: Robert MK, Bonita FS, Joseph WSG, Nina FS, editors. Nelson Textbook of Pediatrics. 20th edition. Philadelphia: ELSEVIER: 2016; 462: 2349-52. 
7. Gomber S, Jain P, Sharma S, Narang M. Comparative Efficacy and Safety of Oral Iron Chelators and their Novel Combination in Children with Thalassemia, J Indian pediatrics 2016, 53: 207-10.

8. Caterina BP, Renzo G. Thalassemias and related disorders. In: John PG, Daniel AA, Bertil G, Alan FL, Robert TM, Frixos P, et al, editors. Wintrobe's Clinical Hematology. 13th edition. Lippincott Williams \& Wilkins: 2014; 34: 19902067.

9. Riaz H, Riaz T, Khan MU, Aziz S, Ullah F, Rehman A et al. Serum ferritin levels, sociodemographic factors and desferrioxamine therapy in multi-transfused Thalassemia major patients at a government tertiary care hospital of Karachi, Pakistan.(Short Report)(Report).J BMC Research Notes 2011;4: 287.

10. Mourad FH, Hoffbrand AV, Sheikh-Taha M, Koussa S, KhoriatyAl ,Taher A. Comparison between desferrioxamine and combined therapy with desferrioxamine and deferiprone in iron overloaded thalassaemia patients. British Journal of Haematology 2003; 121: 187-89.

11. Hassan MAM, Tolba OA. Iron chelation monotherapy in transfusion-dependent betaThalassemia major patients: a comparative study of deferasirox and deferoxamine. J Electronic Physician 2016;8: 2425-31.

12. Farmaki K, Tzoumari I, Pappa C. Oral chelators in transfusion-dependent Thalassemia major patients may prevent or reverse iron overload complications.Blood Cells Mol Dis. 2011;47: 33-40.
13. Balocco M, Carrara P, Pinto V, Forni GL. Daily alternating deferasirox and deferiprone therapy for "hard-to-chelate" beta-Thalassemia major patients. Am J Hematol 2010; 85: 460-1.

14. Voskaridou E, Christoulas D, Terpos E. Successful chelation therapy with the combination of deferasirox and deferiprone in a patient with thalassaemia major and persisting severe iron overload after single-agent chelation therapies.Br J Haematol 2011;154: 654-6.

15. Waheed N, Ali S, Butt MA. Comparison of deferiprone and deferrioxamine for the treatment of transfusional iron overload in children with beta Thalassemia major. J Ayub Med Coll Abbottabad2014; 26: 297-300.

16. Totadri S, Bansal D, Bhatia P. The deferiprone and deferasirox combination is efficacious in iron overloaded patients with $\beta$-Thalassemia major: a prospective, single center, open-label study. JPediatr Blood Cancer 2015; 62: 1592-6.

17. Eshghi R, Farahmandinia Z, Molavi M. Efficacy and safety of Iranian made Deferasirox (Osveral) in Iranian major Thalassemic patients with transfusional iron overload: A one year prospective multicentric open-label noncomparative study. JDARU 2011;19:240-8.

18. Ellis J. Oral chelators deferasirox and deferiprone for transfusional iron overload in thalassemia major: new question. Blood Journal 2006; 107: 2394.

19. Hagag AA, Elfrargy MS, Elfatah MA, El-Lateef AMA. Comparative Study of Deferiprone and Silymarin versus Deferiprone and Placebo as Iron Chelators in Children with Beta Thalassemia with Iron Overload.J Leuk 2014; 2: 130. 